\title{
Measurement of cost efficiency in the European banking industry
}

\author{
Branka Tuškan $^{1, *}$ and Alen Stojanović ${ }^{1}$ \\ ${ }^{1}$ Faculty of Economics and Business, University of Zagreb \\ J. F. Kennedy Sq. 6, 10000 Zagreb, Croatia \\ E-mail: $\langle\{$ bjurcevic, astojanovic\}@efzg.hr〉
}

\begin{abstract}
In this paper we analysed and compared efficiency results in the banking industry using two different approaches: financial indicators and the Data Envelopment Analysis (DEA) methodology. In the indicator-based approach, we used chosen accounting ratios (Return on Assets - ROA, Return on Equity - ROE and Cost to Income Ratio - CIR) and the descriptive statistics methodology to conduct analysis. In the case of DEA, a nonparametric linear programming methodology approach, expenses as input data and income as output data are used for measuring efficiency using the CCR DEA model, BCC DEA model and window analysis DEA technique. The objective of this research is ascertain whether a correlation exists between the results of the different ways of measuring efficiency. In that sense, the main purpose of this research is to draw a more precise conclusion about the efficiency of the banking industry, as tested for the period 2008-2012 on a sample of 28 European banking systems.

The main difference in the obtained results is a lag of values of average accounting ratios in comparison to the results of the DEA methodology. Such a finding suggests that the DEA methodology can be useful in detecting early signs of inadequate business strategies, which can lead to the slowdown of business activity or poorer efficiency results. This can be especially important in times of an unstable financial or macroeconomic environment, as it can assist in detecting early signs of a crisis. In general, the results of both approaches suggest that banking systems in post-transition countries have a higher cost efficiency. Such systems continue to be dominantly financed through long-term deposits and are also exposed to a specific risk. They do business in a specific competitive, financial and macroeconomic environment that significantly influences the prices of financial services (i.e. higher margins), and as a consequence, leads to potentially higher banking sector earnings.
\end{abstract}

Key words: banking industry, efficiency, data envelopment analysis, accounting ratios

Received: September 29, 2014; accepted: March 17, 2016; available online: March 31, 2016

DOI: $10.17535 /$ crorr.2016.0004

\section{Introduction}

This paper uses a mathematical tool to measure banking industry efficiency, in addition to descriptive statistics and analysis of chosen associated accounting

${ }^{*}$ Corresponding author. 
indicators. Accounting profitability ratios in general are common tools for measuring efficiency of bank performance and are simple to calculate and interpret. Those ratios give us valuable information about the financial performance of the banking sector when compared to previous periods, but they are also limited due to variables included in the calculations. In general, the main weakness of ratio analysis is a lack of agreement on the relative importance of various types of input and output. Banking sectors may appear to be operating well even if they have an inadequate business strategy and poor management in certain areas, but as long as they compensate for it by operating better in other areas [22]. Furthermore, accounting ratios fail to take into account a greater number of outputs and inputs, and also fail to assess management actions and investment decisions that affect future as opposed to current performance [22]. Accounting ratios are short-run measures and may be inappropriate for describing the actual efficiency of a bank in the long run. Consequently, simple statistical analysis of accounting ratios and results obtained from such analysis may be insufficient.

Average accounting profitability ratios observed in this paper in the period during and just after the onset of the last financial crisis continued to have relatively high values at the end of 2008, even though the crisis had obviously already influenced the business performance of the banking sector and variables used to calculate accounting profitability ratios. On the other hand, inputs and outputs used in the mathematical approach to measuring efficiency by application of the DEA methodology can be different pairs of variables. In this paper, inputs and outputs used in the DEA approach and the specificity the methodology resulted in lower efficiency scores as early as 2008. Thus, we find that the mentioned disadvantages of Return on Assets (ROA) and Return on Equity (ROE) as the primary observed accounting ratios in this paper can be removed using the DEA methodology to measure efficiency. For this reason, the methodology can be a useful independent, alternative and/or complementary tool for gaining a better understanding and drawing a more precise conclusion about banking sector efficiency. This research is originally because in that past researches on banking efficiency used DEA or an indicator-based approach, both approaches have not been used simultaneously on a sample of entire banking systems as the decision making units (DMUs). Samples from existing researches on banking efficiency generally take into account individual banks in certain banking system(s) as DMUs. This research is also comprehensive since it takes into account all EU member states.

The paper is organized as follows. Following the Introduction in Section 2 (Literature), a few common approaches to measuring the efficiency of financial institutions is given, while noting which of them were used in the research. Firstly, the approach using indicators is briefly explained, along with its advantages and limitations. For the purpose of measuring a bank's efficiency in general, the parametric and non-parametric approach may also be used. For this research the non-parametric approach as being more appropriate based on the 
assumptions given here is selected and briefly explained. In the second part of Section 2, literature is reviewed and the main conclusions from previous research are presented. In Section 3 (Methodology), the chosen indicators (3.1.) and DEA methodology and models including techniques used for this research (3.2) are explained in more detailed. Section 4 (Data) presents the data used in the analysis, while Section 5 identifies and discusses the results of efficiency measurements, first in regard to the indicators (5.1.), secondly the DEA approach (5.2.) and finally a comparative analysis (5.3). Conclusions and proposals for future research are provided in Section 6 (Conclusion).

\section{Literature review}

There are a few common approaches to measuring the efficiency of financial institutions. The first approach to measuring efficiency is to use indicators (ratio) analysis from among several financial institutions and to calculate numerous accounting ratios, providing a measurement of the overall financial soundness of financial institutions and the operating efficiency of its management $[15,30]$. Financial statements are the main source of accounting information used in measuring the operating efficiency of a financial institution. Accordingly, an analysis of the relationship between specific values by calculating the efficiency indicators was carried out. Financial ratios as indicators of a bank's efficiency are divided into four main groups: (1) accounting indicators calculated on the basis of the data from a balance sheet, (2) accounting indicators calculated on the basis of the data from a profit and loss statement, (3) accounting profitability indicators, and (4) market profitability indicators, i.e. investment indicators. Accounting ratios as measures of efficiency in general are easier to calculate given that they are calculated using readily available information in financial statements: net profit or profit before taxes, total or average asset and equity, total income, total expenditure and the like. The most significant profitability indicators (ratios) calculated for banks are ROA, ROE and cost to income ratio (CIR).

The second approach in measuring efficiency is parametric programming, and is generally concerned with the production or expense function base. It is used to estimate the characteristics of the function and measures economies of scale, while assuming all decision-making units (DMUs) are operating efficiently. The analysis conducted in this paper does not include parametric programming in measuring efficiency, as it does not assume that all DMUs are operating efficiently. A parametric approach to efficiency measurement includes the Stochastic Frontier Approach (SFA), the Thick Frontier Approach (TFA), and Distribution Free Approach (DFA) [4].

The third approach uses DMUs efficiency frontiers to construct measures of efficiency and is labelled as a non-parametric programming approach. The approach considers the degree to which total efficiency in the financial sector 
can be improved, and ranks the efficiency scores of DMUs. This efficiency measurement is derived from analysing empirical observations obtained from DMUs for defining productive units, which are characterized by common multiple outputs and common designated inputs [5]. In such terms, certain insufficiencies in the accounting indicators approach to efficiency measurement can be eliminated and conclusions about the efficiency can be improved using the DEA approach. Application of the DEA methodology in efficiency measurement has a wide scope and has been used extensively to assess school efficiency [23, 28]; hospital efficiency [13]; bank efficiency [1, 4, 12, 14, 15, 17, 19, 20, 21, 22, 24, 25, 26, 27]; insurance company efficiency [9, 10, 15, 18], etc. In reviewing the literature, the conclusion is that most studies deal with similar approaches in measuring the relative efficiency of banks over a period of time. However, several differences in specific DEA models and the techniques used do exist, i.e. considered aspects and goals of analyses [27]. DEA Window analysis and Malmquist Index analysis techniques are more specific than, for example, the DEA Charnes-Cooper-Rhodes (CCR) and Banker-Charnes-Cooper (BCC) models, due to analysis of panel data.

In the past, researching banking efficiency has not utilising the DEA approach or accounting indicators analysis simultaneously and/or a sample of the entire banking systems of EU member states in the form of decision-making units (DMUs). A similar research that used the DEA approach as opposed to the accounting approach for measuring the efficiency of Croatian financial institutions was conducted on a sample of 30 individual banks and 19 insurance companies operating in the country in the period from 2005-2009 [15]. The results suggest that the DEA approach for calculating efficiency was better (for CCR and BCC models) and the chosen accounting ratios as they were influenced by the boom in Croatian financial sector prior to the recent crisis [15]. The main difference in the results between those two approaches relates to lag scores after 2008 from efficiency measurement using the accounting approach, i.e. after the onset of the financial crisis. Another research was made on the sample of 26 individual banks operating in Bosnia and Herzegovina in the period 2008-2010 by simultaneously applying the DEA approach and financial indicators approach [19]. Bank efficiency varied throughout the observed period and not all banks performed negatively in the banking sector during the crisis. No significant difference between performance of banks in different entities of Bosnia and Herzegovina and those smaller and larger banks were noticed. A comparative analysis of banking sector efficiency indicators in the Republic of Macedonia in the period from 2007 to 2012 and the 16 CSEE countries for the period 2003-2012 shows that the values of observed indicators shifted around the average value for the entire analyzed sample, suggesting that countries with banking sectors that exhibit lower operating costs had a higher level of financial deepening and greater degree of financial intermediation [20]. At the same time, results of DEA approach suggest that the group of large banks with the highest efficiency was in the Macedonian banking sector. The 
comparison of the results of the DEA and accounting approach in the efficiency testing of the Bulgarian banking system in the period 1999-2006 showed that foreign banks perform better than domestic and state-owned banks due to technological and managerial improvements; and secondly, the large banks are more efficient than small banks due to smaller operating costs and economies of scale [21]. Samples in other researches mostly covered individual banks and were based only on DEA. Efficiency scores (using a sample of 125 large banks from 14 emerging European countries) prior to the crisis suggest a strong correlation with a country's level of development, and also that bank efficiency suffered in the period prior to the crisis when credit activity was expanding, even though efficiency scores increased [1]. Foreign ownership positively influences a banks' efficiency in less developed countries, and there exists a direct correlation between a bank's cost efficiency (sample of 20 emerging European countries, 1993-2004) and economic reforms and stability, capital regulation and market structure in the banking sector [25]. Banking sectors (sample of 289 banks in 15 East European countries, 1994-2001) in which foreign owned banks have a larger share of total assets operate with lower expenses and also progress in banking reform exhibits a non-linear association with cost efficiency [12]. An averagesized bank in the sample operated at a point close to constant returns to scale, while smaller banks operated with significant unrealised economies of scale. Consolidation of smaller banks contributes to greater cost efficiency in banking, with private banks more cost efficient than state-owned banks, while privatised banks in majority foreign ownership are the most efficient whereas those in domestic ownership are the least efficient [12]. Smaller banks (sample of Croatian banks, period 1995-2000) are globally efficient, but large banks are locally efficient; foreign owned banks on average are the most efficient, while new banks are more efficient than previously established banks [14].

\section{Methodology}

\subsection{Indicators approach}

The accounting bank profitability indicators calculated for research criteria are ROA, ROE and CIR. ROA is determined by model that includes the profit before taxes divided by average asset [30]. It is the most important ratio in comparing the efficiency and operating performance of banks as it indicates the returns generated from the assets financed by them [16]. For that reason, ROA can also be observed as a measure of a bank's management quality. To calculate the indicator ROE, the following model is applied: profit before taxes is divided by the average shareholder's equity [30]. Subsequently, ROE measures the return on investment made by an investor's equity. In other words, ROE measures how much profit (in \%) is earned by the unit of shareholder's equity. ROA is a commonly used accounting ratio and a key measure of a bank's 
operating efficiency [15]. The commonly accepted efficiency frontier for a value of ROA is at least $1 \%$ and for ROE at least $15 \%$ in a boom period, whereas in a recession period each bank with a ROE value of at least $10 \%$ is considered profitable, i.e. efficient. CIR is calculated as a share of a bank's operating expenses (general administrative expenses and amortization) in net income [30]. For the purpose of this research values of ROA, ROE and CIR accounting efficiency indicators on the level of EU were analysed as a result of applying simple descriptive statistics methods (minimum - MIN, maximum-MAX, average-MEAN and median-MEDIAN). In the statements from the Croatian banking sector, Return on Average Assets (ROAA) and Return on Average Equity (ROAE) were analysed. They take into account the average values of assets/equity instead of total values, as in case of ROA and ROE. ROAA represents pre-tax profit as a $\%$ of average assets. ROAE represents the aftertax profit as a \% of average equity. Accounting indicators, in general, are shortrun measures and may be inappropriate for describing the actual efficiency of a bank in the long run. Consequently, simple statistical analysis of accounting ratios and results obtained from such analysis may have shortages, in terms of operating efficiency measurement.

\subsection{DEA approach}

DEA is specifically a mathematical nonparametric linear programming methodology used to measure efficiency and enjoys a number of advantages over other traditional parametric efficiency measurement approaches. In that sense, shortages of the accounting indicators approach for efficiency measurement mentioned earlier are eliminated by the DEA approach. If the goal is to calculate the indicator of business performance representing the efficiency of an organizational unit within a financial institution, then the input and output ratio is used. Thus, if we want to calculate the efficiency measure that takes into account a number of inputs and outputs, it becomes necessary to make a selection of those that will be included in the calculation and assign them certain weights in order to determine a unique efficiency measure. The methodology that enables this is data envelopment analysis. Unlike statistical approaches that derive estimations on the basis of the average production unit, DEA is an extreme point methodology in which each DMU is compared only to the best one. For observed inputs and outputs of the DMU's, the assumption is that a connection exists between them, but the shape of that connection is not defined, which is the case with statistical approaches. DEA is most useful in cases where accounting and financial ratios are of little value, multiple outputs are produced through the transformation of multiple inputs, and the inputoutput transformation relationships are not known [5]. The results of DEA can help DMUs to improve their business results. The basic idea behind DEA is to identify the most efficient DMU from among all DMUs, where the set of best practice or frontier observations are those for which no other DMU or linear 
combination of units has as much or more of every output (given inputs) or as little or less of every input (given outputs) [4].

As a result, different DEA models give different types of efficiency. The CCR-model [6, p.p. 23, 24, 43] assumes constant returns to scale (CRS) and provides a measure of global technical efficiency $[2,6]$. On the other hand, the BCC-model [6, p.p. 87] assumes variable returns to scale (VRS), and as a result gives pure local technical efficiency $[2,6]$. If the DMU is perfectly efficient based on both models, then its efficiency with respect to returns to scale is the highest. When output is increasing by the same factor as input, then it is CRS. If an increase in inputs does not result in a proportional change in the outputs, then it is VRS. A particular version of the CCR-model aims to minimize inputs while satisfying at least the given output levels; this is called the input-oriented model.

Another version is called the output-oriented model, and attempts to maximize outputs without requiring more of the observed input values [6, p.p. 41]. Assumptions of the output-oriented model are chosen for the purpose of this research as well. An optimal solution to the linear problem in the CCR-model is $\left(\vartheta *, v^{*}, u^{*}\right)$, where $v$ and $u$ represent input and output weight vectors. In that sense, $\mathrm{DMU}_{0}$ is CCR-efficient if $\vartheta^{*}=1$ and there exists at least one optimal ( $v^{*}$, $u^{*}$ ) with $v^{*}>0$ and $u^{*}>0$, otherwise $\mathrm{DMU}_{0}$ is CCR-inefficient [6, p.p. 24, 25]. An optimal solution $\left(\lambda *, s^{*}, s^{* *}\right)$ of the Phase II linear programming problem used to discover the possible input excesses and output shortfalls is called the max-slack solution [6, p.p. 44, 45]. "Slack" vectors $\left(s^{-}, s^{+}\right)$represent input excesses and output shortfalls. The objective of Phase II therefore is to find a solution that maximizes the sum of input excesses and output shortfalls while maintaining $\vartheta=\vartheta^{*}$. If the max-slack solution satisfies $s^{* *}=0$ and $s^{+*}=0$, then it is called zero-slack. Further, a $\mathrm{DMU}_{0}$ is called CCR-efficient (Radial Efficiency or Technical Efficiency) if an optimal solution $\left(\vartheta^{*}, \lambda *, s^{*}, s^{+*}\right)$ of the two-phase linear programming problem of discovering the possible input excesses and output shortfalls satisfies both, $\boldsymbol{\vartheta}^{*}=1$ and is zero-slack $\left(s^{*}=0\right.$ and $s^{+*}=0$ ), otherwise it is called CCR-inefficient [6, p.p. 45]. A DMU is called weakly efficient if $\vartheta^{*}=1$ and $s^{*} \neq 0$ and (or) $s^{+*} \neq 0$. In that sense, a DMU is fully efficient if and only if any input or output cannot be improved without worsening some other input or output (Pareto-Koopmans Efficiency) [6, p.p. 45]. If an optimal solution $\left(\vartheta_{B}^{*}, \lambda *, s^{*}, s^{* *}\right)$ obtained in the two-phase linear programming problem for $\mathrm{BCC}_{\mathrm{o}}$ satisfies $\vartheta^{*}{ }_{B}=1$ and has no slack $\left(s^{*}=0, s^{+*}\right.$ $=0$ ), then the $\mathrm{DMU}_{0}$ is called BCC-efficient, otherwise it is BCC-inefficient $[6$, p.p. 87,88$]$.

The window analysis technique is specific, when compared to the $\mathrm{BCC}$ or CCR models for instance, due to analysis of panel data. Due to the reason that window analysis is based on panel data, it is better to capture the variations of efficiency over time and use them as the more appropriate tool for efficiency measurement of the European banking systems in this research as well, but the 
results are compared also with the results of CCR and BCC models. Window analysis is a DEA technique for examining changes in the efficiencies of a set of DMUs over time. A set of time periods (1..t) is chosen and the efficiency of each DMU (1..n) is computed separately for each period so that the efficiency of a given DMU over each period is treated like a new DMU resulting in the total number of $t n$ DMUs. Window analysis assesses the performance of a DMU over time by treating it as a different entity in each time period. For example, if there are $n$ units with data on their input and output measures in $k$ periods, then a total of $n k$ units need to be assessed simultaneously to capture the efficiency variations over time. For $n=$ number of DMUs, $k=$ number of periods, $p=$ length of window ( $p$ less or equal $k$ ) the number of "different" DMUs is $n p(k-p+1)$ [6, p.p. 295]. In classical window analysis, when a new period is introduced into the window the earliest period left out.

However, some critical factors must be considered when applying the DEA models. The efficiency scores might be very sensitive to data changes and depend heavily on the number and type of input and output factors considered. In general, inputs can include any resources utilized by a DMU, and the outputs can range from actual products produced to a range of performance and activity measures [29]. In that regard, there are a few different approaches that can be used for measuring relative efficiency in the banking sector:

- The Production Approach views a bank as a producer of services and products using labour and other resources as inputs and providing deposits, loans and other services (in value or number of transactions) as outputs [7];

- The Intermediation Approach studies the intermediary role of a bank in order to examine how efficient the bank is in collecting deposits and other funds from customers (inputs) and then lending out the money in various forms of loans, mortgages, and other assets (i.e., investments, etc.) [7];

- The Profitability Approach examines the process of how well a bank uses its inputs (expenses) to produce revenues [24].

This research uses the profitability approach (analysis of bank profit efficiency) on a set of input and output data for estimating efficiency. This is the basis for choosing output-oriented DEA models in this analysis, which in that regard provides efficiency trends and ranks each banking system of EU member states, in terms of profit and operating effectiveness.

\section{Data}

The selected general data from consolidated financial statements for the EU-27 are shown in Table 1, and for the Croatian banking sector in Table 2, this in light of the fact that the Republic of Croatia was not an EU member state in the observed period of this research. However, country is also included in the 
sample for DEA analysis because the assumption is that comparing the performance of the Croatian banking sector with other EU banking sectors would be interesting, given that about $90 \%$ of assets in the Croatian banking sector are in foreign ownership (mostly Austrian and Italian) and compliance by Croatian banks with regard to business performance (legal and practical) was already at a very high level in that period when compared with banks in EU countries (such compliance was a prerequisite for finalising accession negotiations). As a consequence, it is assumed that input and output data for Croatia are comparable to those in the EU banking sector and can be used in DEA analysis (in all, 28 DMUs).

\begin{tabular}{|l|c|c|c|c|c|}
\hline & 2008 & 2009 & 2010 & 2011 & 2012 \\
\hline $\begin{array}{l}\text { Number of credit institutions, } \\
\text { EU-27 }\end{array}$ \\
\hline $\begin{array}{l}\text { Stand-alone credit institutions } \\
\text { Banking groups }\end{array}$ & $\begin{array}{c}4,500 \\
484\end{array}$ & $\begin{array}{c}4,448 \\
452\end{array}$ & $\begin{array}{c}4,350 \\
418\end{array}$ & $\begin{array}{c}4,296 \\
417\end{array}$ & $\begin{array}{c}4,213 \\
398\end{array}$ \\
\hline $\begin{array}{l}\text { Domestic credit institutions } \\
\text { Foreign-controlled } \\
\text { subsidiaries/branches }\end{array}$ & 3,928 & 3,859 & 3,730 & 3,691 & 3,609 \\
\hline Total & 1,056 & 1,041 & 1,038 & 1,022 & 1,003 \\
\hline $\begin{array}{l}\text { Total assets of credit institutions (EU-27, in EUR } \\
\text { billions) }\end{array}$ & 4,984 & 4,900 & 4,768 & 4,713 & 4,612 \\
\hline $\begin{array}{l}\text { Domestic credit institutions } \\
\text { Foreign subsidiaries and } \\
\text { branches }\end{array}$ & $37,770.8$ & $34,663.5$ & $34,638.0$ & $35,901.6$ & $35,471.9$ \\
\hline
\end{tabular}

Table 1: EU-27 consolidated banking data [11]

\begin{tabular}{|l|c|c|c|c|c|}
\hline \multicolumn{1}{|c|}{ The Republic of Croatia } & 2008 & 2009 & 2010 & 2011 & 2012 \\
\hline Number of credit institutions & 43 & 43 & 38 & 37 & 36 \\
\hline Number of commercial banks & 35 & 34 & 32 & 31 & 30 \\
\hline Total assets of CI (in EUR billions) & 50.3 & 51.7 & 53.7 & 54.9 & 54 \\
\hline
\end{tabular}

Table 2: General banking data for the Republic of Croatia (HR) [8]

The data in the above two tables serve primarily to show size-linked relations between EU-27 countries and the Republic of Croatia, the relative importance of the Republic of Croatia in light of the European banking industry as a whole, and consequently, its influence on the comparability of results from both approaches. The sample in this study involves 28 European banking systems (EU-27 and the Republic of Croatia) and data sets for the period 20082012, given that the crisis strongly affected the business performance results of banks especially in this period. An analysis was carried out of the values of ROA, ROE and CIR accounting efficiency indicators at the EU level, resulting from the application of simple descriptive statistics on data for all EU-27 countries (in \%, Appendix 1). When average values were calculated, (excluded) minimum and maximum values (outliers - countries with values significantly 
higher/lower than average) were considered, in order to obtain more objective and comparable results. When performing statistical analysis of accounting indicators for the Republic of Croatia, only ROAA and ROAE were available as Croatia was observed separately (excluded from the calculation of values at the EU level). Given that the relative importance of Croatia in terms of compared data (Table 1 and 2) is obviously very small, the assumption is that does not exert a greater influence on the comparability of results.

All input and output data used in the DEA analysis models and previously calculated, official accounting indicators analysed by using descriptive statistics methods are taken from the European Central Bank database (Consolidated banking data; for EU-27 [11]) and from Croatian National Bank (official data, for the Republic of Croatia [8]). In the case of the DEA approach, 28 European banking systems were viewed as 28 DMUs in the period 2008-2012. The data set used for DEA analysis (in the CCR model, BCC model and in window analysis, DEA-Solver-Pro software used) is given in Appendix 2. For each j-th DMU (i.e. for each banking system) inputs ( $\mathrm{x}_{\mathrm{ij}}$ ) include (in EUR billions):

Input $1,\left(\mathrm{x}_{1 \mathrm{j}}\right) \rightarrow$ interest expenses

Input 2, $\left(\mathrm{x}_{2 \mathrm{j}}\right) \rightarrow$ total operating expenses [sum of two positions: fee and commission expenses and other operating expenses (labour-related and capitalrelated administrative expenses and other expenses from the business activity of a bank)].

On the other side, output data $\left(\mathrm{y}_{\mathrm{ij}}\right)$ include:

Output $1,\left(\mathrm{y}_{1 \mathrm{j}}\right) \rightarrow$ interest income

Output 2, $\left(\mathrm{y}_{2 \mathrm{j}}\right) \rightarrow$ total operating income (fee and commission, and other operating income).

The core business activity of banks is assumed to be the collection of deposits, lending transactions and payment operations. Such activities provide the main categories of incomes and expenses. The interest income category assumes income from interest earned in a bank's lending activities and related revenues while total operating income includes income from fees and commissions, other related revenues and other incomes from business activity. On the other hand, expenses from a bank's business activity include: interest expenses that arise from collection of deposits and related expenses and operating expenses which include expenses for fees and commissions, other related expenses, and the category other operating expenses which includes: labour-related administrative expenses (employee costs), capital-related administrative expenses (depreciation, office supplies, etc.) and other expenses from the business activity of a bank. 


\section{Results}

\subsection{Indicators approach}

The worst average and median values of accounting indicators ROA and CIR at the level of EU-27 occurred in 2009 (see Table 3). In the case of ROE, the lowest value occurred in 2012 due to the negative effect of the widest spread between MIN (Cyprus) and MAX (Estonia) values in that very year. If we exclude country outliers from the calculation, the absolute lowest ROE was also recorded in the year 2009.

\begin{tabular}{|c|c|c|c|c|c|}
\hline & & MIN & MAX & MEAN & MEDIAN \\
\hline \multirow[t]{3}{*}{2008} & $\mathrm{ROA}$ & $\begin{array}{l}-1.5 \\
(\mathrm{BE})\end{array}$ & $\begin{array}{c}2.0 \\
(\mathrm{BG})\end{array}$ & $\begin{array}{c}0.44 \\
(\text { HR } 1.60)\end{array}$ & 0.40 \\
\hline & $\mathrm{ROE}$ & $\begin{array}{l}-44.8 \\
(\mathrm{BE})\end{array}$ & $\begin{array}{l}18.8 \\
(\mathrm{RO})\end{array}$ & $\begin{array}{c}4.40 \\
\text { (HR 9.91) }\end{array}$ & 5.20 \\
\hline & CIR & $\begin{array}{c}-186.2 \\
(\mathrm{NL})\end{array}$ & $\begin{array}{l}-40.5 \\
(\mathrm{EE})\end{array}$ & $\begin{array}{c}-63.37 \\
(\text { HR } 52.40)\end{array}$ & -55.20 \\
\hline \multirow[t]{3}{*}{2009} & $\mathrm{ROA}$ & $\begin{array}{l}-4.0 \\
(\mathrm{LV}) \\
\end{array}$ & $\begin{array}{c}1.8 \\
(\mathrm{MT}) \\
\end{array}$ & $\begin{array}{c}-0.10 \\
(\text { HR } 1.13) \\
\end{array}$ & 0.20 \\
\hline & $\mathrm{ROE}$ & $\begin{array}{l}-70.1 \\
(\mathrm{LT})\end{array}$ & $\begin{array}{l}22.5 \\
(\mathrm{HU})\end{array}$ & $\begin{array}{c}-2.83 \\
(\text { HR 6.40) }\end{array}$ & 4.00 \\
\hline & CIR & $\begin{array}{l}-76.7 \\
(\mathrm{BE})\end{array}$ & $\begin{array}{l}-18.8 \\
(\mathrm{MT})\end{array}$ & $\begin{array}{c}-53.36 \\
\text { (HR 49.50) }\end{array}$ & -55.00 \\
\hline \multirow[t]{3}{*}{2010} & $\mathrm{ROA}$ & $\begin{array}{l}-3.1 \\
(\mathrm{IE}) \\
\end{array}$ & $\begin{array}{c}1.3 \\
(\mathrm{CZ}) \\
\end{array}$ & $\begin{array}{c}0.2 \\
(\text { HR 1.12) }\end{array}$ & 0.40 \\
\hline & $\mathrm{ROE}$ & $\begin{array}{c}-65.2 \\
\text { (IE) }\end{array}$ & $\begin{array}{l}15.2 \\
(\mathrm{CZ}) \\
\end{array}$ & $\begin{array}{c}1.9 \\
\text { (HR 6.46) }\end{array}$ & 5.99 \\
\hline & CIR & $\begin{array}{c}-412.2 \\
\text { (IE) }\end{array}$ & $\begin{array}{c}-26 \\
(\mathrm{MT})\end{array}$ & $\begin{array}{c}-69.0 \\
(\mathrm{HR} 48.00)\end{array}$ & -57.45 \\
\hline \multirow[t]{3}{*}{2011} & $\mathrm{ROA}$ & $\begin{array}{l}-4.0 \\
(\mathrm{CY})\end{array}$ & $\begin{array}{c}3.1 \\
(\mathrm{EE}) \\
\end{array}$ & $\begin{array}{c}0.20 \\
\text { (HR 1.17) }\end{array}$ & 0.23 \\
\hline & $\mathrm{ROE}$ & $\begin{array}{l}-86.0 \\
(\mathrm{CY}) \\
\end{array}$ & $\begin{array}{l}25.5 \\
(\mathrm{EE}) \\
\end{array}$ & $\begin{array}{c}0.31 \\
\text { (HR 6.88) }\end{array}$ & 4.20 \\
\hline & CIR & $\begin{array}{l}-72.1 \\
(\mathrm{AT})\end{array}$ & $\begin{array}{l}-30.4 \\
(\mathrm{MT})\end{array}$ & $\begin{array}{c}-55.84 \\
(\mathrm{HR} 42.80)\end{array}$ & -55.84 \\
\hline \multirow[t]{3}{*}{2012} & $\mathrm{ROA}$ & $\begin{array}{l}-3.4 \\
(\mathrm{CY}) \\
\end{array}$ & $\begin{array}{c}2.0 \\
(\mathrm{EE})\end{array}$ & $\begin{array}{c}-0.01 \\
(\text { HR } 0.86) \\
\end{array}$ & 0.20 \\
\hline & $\mathrm{ROE}$ & $\begin{array}{l}-90.3 \\
(\mathrm{CY}) \\
\end{array}$ & $\begin{array}{l}14.2 \\
(\mathrm{EE})\end{array}$ & $\begin{array}{c}-4.51 \\
(\text { HR } 4.84)\end{array}$ & 3.42 \\
\hline & CIR & $\begin{array}{c}-92.7 \\
\text { (IE) }\end{array}$ & $\begin{array}{l}-25,1 \\
(\mathrm{MT})\end{array}$ & $\begin{array}{c}-59.62 \\
(\text { HR } 50.30)\end{array}$ & -58.59 \\
\hline
\end{tabular}

* AT-Austria, BE-Belgium, BG-Bulgaria, CY-Cyprus, CZ-Czech Rep., EE-Estonia, IEIreland, GR-Greece, HR-Croatia, HU-Hungary, MT-Malta, RO-Romania

Table 3: The results of statistical analysis of chosen accounting efficiency indicators for the EU-27 and average values for the Republic of Croatia (HR) [8, 11] 
The Republic of Croatia recorded its lowest average values for accounting indicators in 2012 (Tables 3 and 4). This lag in comparison to the EU-27 can be explained due to the great recession and specific political, macroeconomic and financial conditions in Croatia, which annually deteriorated between 2008 and 2012, and even after that. As a consequence, there also exists a significant lag of effects on banking sector accounting ratios. The best indicators of average values were recorded in 2008, given that the crisis had not yet affected results.

\subsection{The DEA approach}

The results of the DEA approach (Table 4) suggest different conclusions about EU banking sector efficiency, depending on the model/technique used and on the type of results observed, but they also differ in comparison to the results of the accounting indicators approach.

\begin{tabular}{|c|c|c|c|c|c|}
\hline & 2008 & 2009 & 2010 & 2011 & 2012 \\
\hline \multicolumn{6}{|c|}{ Statistical analysis of the accounting efficiency indicators approach } \\
\hline \multicolumn{6}{|c|}{ EU-27 (Average values) } \\
\hline $\begin{array}{l}\text { ROA (\%) } \\
\text { ROA (\%) without outliers }\end{array}$ & $\begin{array}{c}0.44 \\
0.51(\mathrm{BE})\end{array}$ & -0.10 & $\begin{array}{c}0.20 \\
0.32(\mathrm{IE})\end{array}$ & $\begin{array}{c}0.20 \\
0.37(\mathrm{CY}, \mathrm{GR})\end{array}$ & $0.24(\mathrm{CY}, \mathrm{GR})$ \\
\hline $\begin{array}{l}\text { ROE (\%) } \\
\text { ROE }(\%) \text { without outliers }\end{array}$ & $\begin{array}{c}4.40 \\
6.22(\mathrm{BE})\end{array}$ & $\begin{array}{c}-2.83 \\
-0.25(\mathrm{LT})\end{array}$ & $\begin{array}{c}1.87 \\
4.45(\mathrm{IE})\end{array}$ & $\begin{array}{c}0.31 \\
3.76(\mathrm{CY}, \mathrm{GR})\end{array}$ & $1.81(\mathrm{CY}, \mathrm{GR})$ \\
\hline $\begin{array}{l}\text { CIR (\%) } \\
\text { CIR (\%) without outliers }\end{array}$ & $\begin{array}{c}-63.37 \\
-58.64(\mathrm{NL})\end{array}$ & -53.40 & $\begin{array}{c}-69.00 \\
-55.73(\mathrm{IE})\end{array}$ & -55.84 & $\begin{array}{c}-59.62 \\
-57.88(\mathrm{IE})\end{array}$ \\
\hline \multicolumn{6}{|l|}{ The Republic of Croatia } \\
\hline ROAA (\%) & 1.60 & 1.13 & 1.12 & 1.17 & 0.86 \\
\hline ROAE (\%) & 9.91 & 6.40 & 6.46 & 6.88 & 4.84 \\
\hline CIR $(\%)$ & 52.40 & 49.50 & 48.00 & 42.80 & 50.30 \\
\hline \multicolumn{6}{|c|}{ DEA approach } \\
\hline \multicolumn{6}{|c|}{ window analysis, output oriented, $\mathrm{CRS}$ (length of window $=5$, average by term) } \\
\hline No. of DMUs & 28 & 28 & 28 & 28 & 28 \\
\hline No. of efficient DMUs & 0 & 1 & 1 & 2 & 1 \\
\hline Average relative efficiency & 0.659 & 0.715 & 0.727 & 0.732 & 0.726 \\
\hline \multicolumn{6}{|c|}{ CCR - model, output-oriented, CRS } \\
\hline No. of DMUs & 28 & 28 & 28 & 28 & 28 \\
\hline No. of efficient DMUs & 5 & 3 & 4 & 4 & 4 \\
\hline Average relative efficiency & 0.833 & 0.794 & 0.789 & 0.769 & 0.766 \\
\hline SD & 0.125 & 0.109 & 0.126 & 0.134 & 0.134 \\
\hline $\begin{array}{l}\text { No. of DMUs - efficiency } \\
\text { lower than average }\end{array}$ & 15 & 16 & 15 & 16 & 18 \\
\hline \multicolumn{6}{|c|}{ BCC - model, output-oriented, VRS } \\
\hline No. of DMUs & 28 & 28 & 28 & 28 & 28 \\
\hline No. of efficient DMUs & 15 & 13 & 12 & 14 & 11 \\
\hline Average relative efficiency & 0.966 & 0.920 & 0.944 & 0.955 & 0.931 \\
\hline SD & 0.046 & 0.091 & 0.084 & 0.061 & 0.075 \\
\hline $\begin{array}{l}\text { No. of DMUs - efficiency } \\
\text { lower than average }\end{array}$ & 11 & 12 & 9 & 11 & 11 \\
\hline
\end{tabular}

Table 4: European banking system efficiency measurement summary results 
According to the CCR-model (output-oriented, CRS), the worst average relative efficiency was recorded in 2012 and the highest in 2008. The smallest number of efficient DMUs was recorded in 2009. In the case of the BCC-model (output-oriented, VRS), the lowest average efficiency was recorded in 2009 and the highest level as well as the number of efficient DMUs in 2008 was identical to that of CCR-model. For the case of DEA window analysis, efficiency results suggest that 2008 was the worst year with respect to average relative efficiency and the number of efficient DMUs, whereas 2011 was the best year.

\subsection{Comparative analysis of the results}

The results of DEA efficiency analysis acquired from CCR and BCC outputoriented models and window analysis, including the statistical analysis results of accounting efficiency indicators are compared in the Table 4. The main difference in the observed results indicates a lag of the average accounting indicators with respect to the results of DEA window analysis approach for efficiency measurement. In that regard, efficiency scores from DEA window analysis, the average for EU-28 (table 4) and for each country in the sample separately observed as well (Appendix 6) generally had the lowest values in 2008. This can be explained due to the onset of the financial crisis in that year, which affected input and output data used in DEA approach more than variables used in calculating the already existing accounting ratios in that year. The average in window order by rank suggests also that the best results (greater than the average, Appendix 5) occur most often in the banking systems of posttransition and other EU-12 countries (Croatia, Czech Republic, Slovakia, Hungary, Poland, Romania, Bulgaria, etc.), where financing based on deposits prevails, whereas other sources of financing have a relatively low significance, most often up to $10 \%$.

Similar results for each country in the sample observed separately (relative efficiency $=1$ or an above-average efficiency; Appendices 3 and 4) are provided by the CCR and BCC models. However, those systems also exhibit a specific competition environment, risk exposure, a financial and macroeconomic environment, significantly influencing the price of financial services (i.e. higher margins) and as a consequence, potentially higher banking sector earnings. Such results are also explained by the fact that the last global financial and economic crisis had a significantly higher impact on well-developed banking systems, exposure to mortgage securities instruments as relatively significant sources of financing in terms of long-term lending activities. The Republic of Croatia, which was not EU member state in the observed period, had in absolute terms the best DEA efficiency results (relative efficiency $=1$ with a rank of 1 ) in all years in the CCR and BCC models in comparison to the other countries in the sample observed (with the exception of 2009 when it was ranked fourth). The 
window analysis also showed that it accomplished the best results when observing the average based on window results (Appendix 5).

When considering all these facts, a more precise interpretation of such results cannot be given. $\mathrm{CCR}$ and $\mathrm{BCC}$ models did not provide comparable results. The results indicating the number of efficient DMUs and average relative efficiency scores for the $\mathrm{BCC}$ model are better due to the fact that $\mathrm{BCC}$ model is based on VRS. However, the CCR model based on CRS is better when observing the efficiency of financial institutions because under VRS, the majority of large banks (banking sectors in this case) might appear as fully efficient, due to the lack of truly comparable efficient banks [1,3]. Given that the DEA window analysis is based on panel data, the assumption is that it provides a better efficiency measurement, analysis results and conclusions when compared to the CCR and BCC models. This is especially true when comparing DEA results with the efficiency results of the average accounting indicators approach, and also when analysing a sample similar to that observed in this research, and observing entire banking systems as DMUs.

\section{Conclusion}

One of the main aims of the paper is to determine whether there exists a correlation between the average efficiency results at the EU level and individual results for countries included in the sample. Another aim was to observe trends of results in a given period and based on different efficiency measurement approaches. Based on such analysis, the paper provided a more precise conclusion about the efficiency of the EU banking industry. The main difference in the research results indicates a lag of average accounting indicators over the results of the DEA window analysis approach for efficiency measurement. The DEA window analysis was recognized as the better tool in comparison to the CCR and BCC models for efficiency measurement, as it assumes analysis of panel data. Further, it was also recognized as the better tool when comparing DEA results with the results of indicator-based approach.

Efficiency scores from the DEA window analysis had their lowest values in 2008. On the other hand, average ROA and ROE accounting ratios had the lowest values in 2009. This may be explained by the fact that although banks operate more efficiency in times of crisis, were expense and income results are used as inputs/outputs in the DEA approach to efficiency measurement, variables in accounting ratio calculations did not achieve results as good as in boom times, due to deteriorating market conditions and a more conservative business strategy by banks in crisis periods. If the input and output values used in the window analysis of this research are observed as accounting efficiency indicators, the same conclusion can be deduced in the case of ROA and ROE. Such a finding suggests that the DEA methodology can be a useful alternative 
or complementary analytical tool for detecting early signs of inadequate business strategies, which in turn can lead to a slowdown of business activity or poorer efficiency results. Importantly, this is also true in times of an unstable financial or macroeconomic environment, as it may facilitate detecting early signs of a crisis, earlier than when using accounting indicators.

Finally, a comparison of the results of both approaches may facilitate drawing more precise conclusions about banking industry efficiency. In general, results from efficiency measurement using those two different approaches suggest that greater cost efficiency are attributed to deposit-oriented banking systems of post-transition countries, where banks operate in specific environments and therefore are able to theoretically achieve higher earnings. Such results can be explained by the fact that the last global financial and economic crisis had a significantly higher impact on banking systems exposed to mortgage securities instruments as relatively significant sources of financing long-term lending activities. This research is important because the DEA methodology and statistical analysis of accounting indicators were previously used for ascertaining the efficiency measurement and comparing efficiency results of banks solely with entire banking systems acting as decision making units. Suggestions for future research include comparing window analysis results with the results of Malmquist Index analysis, and considering other pairs of inputs and outputs. Further research might be able to classify banking sectors (or individual banks) into two groups, depending on whether they are developed or post-transitional, or into additional groups depending on whether they are "large", "medium" or "small" in terms of the asset size of DMUs as a percentage of total assets. In addition, ongoing research could also compare the efficiency scores of each one of these groups with the results of other groups, and their total average efficiency scores. The result of this multi-group classification, in addition to more variables and more advanced methodologies, could become an even better analytical tool for determining key factors of efficiency with respect to accounting indicators.

\section{References}

[1] Anayiotos, G., Toroyan, H. and Vamvakidis, A. (2010). The efficiency of emerging Europe's banking sector before and after the recent economic crisis. Financial Theory and Practice, 34, 247-267.

[2] Banker, R. D., Charnes A. and Cooper W. W. (1984). Some models for estimating technical and scale inefficiencies in Data Envelopment Analysis. Management Science, 30(9), 1078-1092.

[3] Berg, S. A., Hjalmarsson, F. and Suominen, M. (1993). Banking efficiency in the nordic countries. Journal of Banking and Finance, 17, 371-388. 
[4] Berger, A. N. and Humphrey, D. B. (1997). Efficiency of financial institutions: International survey and directions for future research. European Journal of Operational Research, 98, 175-212.

[5] Charnes, A., Cooper, W. W. and Rhodes, E. (1978). Measuring the efficiency of decision making units. European Journal of Operational Research, 2, 429-444.

[6] Cooper W. W., Seiford L. M. and Tone, K. (2006). Introduction to Data Envelopment Analysis and Its Uses With DEA-Solver Software and References. New York: Springer.

[7] Cooper, W.W., Seiford, L.M. and Zhu, J. (2011). Handbook on DEA. $2^{\text {nd }}$ edt. Springer.

[8] Croatian National Bank (CNB). Official data. Available at: http://www.hnb.hr/statistics/ [Accessed on September 10, 2015].

[9] Cummins, J. D. and Weiss, M. A. (1998). Analyzing firm performance in the insurance industry using frontier efficiency methods. Working Paper, Philadelphia: Wharton.

[10] Davosir Pongrac, D. (2006). Insurance companies' efficiency in the Republic of Croatia, (In Croatian). Master thesis, Zagreb: Faculty of Economics and Business.

[11] European Central Bank (ECB). Official data. Available at: http://www.ecb.europa.eu/stats/money/consolidated/html/index.en.html/ [Accessed September 10, 2015].

[12] Fries, S. and Taci, A. (2005). Cost efficiency of banks in transition: Evidence from 289 banks in 15 post-communist countries. Journal of Banking and Finance, 29, 5581.

[13] Jacobs, R., Smith, P. C. and Street, A. (2006). Measuring Efficiency in Health Care: Analytic Techniques and Health Policy. Cambridge University Press.

[14] Jemrić, I. and Vujčić, B. (2002). Efficiency of banks in Croatia: A DEA approach. Comparative Economic Studies, 44(2-3), 169-193.

[15] Jurčević, B. and Mihelja Žaja, M. (2013). Banks and insurance companies efficiency indicators in the period of financial crisis: The case of the Republic of Croatia. Economic Research, 26,203-224.

[16] Kosmidou, K., Pasiouras, F., Zopounidis C. and Doumpos, M. (2006). A multivariate analysis of the financial characteristics of foreign and domestic banks in the UK. The International Journal of Management Science, 34(2), 189-195.

[17] Kraft, E. and Tirtiroglu, D. (1998). Bank efficiency in Croatia: A stochastic-frontier analysis. Journal of Comparative Economics, 26, 282-300.

[18] Mahlberg, B. and Url, T. (2000). The transition to the single market in the German insurance industry. Working Paper, Vienna: Vienna University of Economics and Business Administration.

[19] Memic, D., and Shkaljic-Memic, S. (2013). Performance analysis and benchmarking of commercial banks operating in Bosnia and Herzegovina: A DEA approach. Business Systems Research, 4(2), 4-24.

[20] Naumovska, E. and Cvetkoska, V. (2015). Efficiency of the Macedonian banking Sector. Yugoslav Journal of Operations Research (Online). Available at: http://dx.doi.org/10.2298/YJOR150228019N/ [Accessed on March 14, 2015].

[21] Nenovsky, N., Chobanov, P., Mihaylova, G., and Koleva, D. (2008). Efficiency of the Bulgarian banking system: Traditional approach and Data Envelopment Analysis. Agency for Economic Analysis and Forecasting, Working paper. 
[22] Neralić, L. (1996). About some uses of DEA in banking sector (In Croatian). Ekonomija - časopis za ekonomsku teoriju i politiku, 3(2), 493-495.

[23] Norman, M. and Stocker, B. (1991). Data Envelopment Analysis: The Assessment of Performance. Chichester: Wiley.

[24] Paradi, J. C., Rouatt, S. and Zhu, H. (2011). Two-stage evaluation of bank branch efficiency using data envelopment analysis. Omega, 39(1), 99-109.

[25] Poghosyan, T. and Kumbhakar, S. C. (2010). Heterogeneity of technological regimes and banking efficiency in former socialist economies. Journal of Productivity Analysis, 33(1), 19-31.

[26] Poghosyan, T. and Poghosyan, A. (2010). Foreign bank entry, bank efficiency and market power in Central and Eastern European Countries. Economics of Transition, 18(3), 571-598.

[27] Savić, G., Radosavljević, M. and Ilievski, D. (2012). DEA window analysis approach for measuring the efficiency of Serbian banks based on panel data. Journal for Theory and Practice Management, 65, 5-14.

[28] Soteriou, A. C., Karahanna, E., Papanastasiou, C., Diakourakis, M. S. (1998). Using DEA to evaluate the efficiency of secondary schools: the case of Cyprus. International Journal of Educational Management, 12/2, MCB University Press, $65-73$.

[29] Talluri, S. (2000). Data Envelopment Analysis: Models and extensions. Decision Line, 31, 8-11. (Online). Available at: http://www.decisionsciences.org/decisionline/Vol31/31_3/31_3pom.pdf/ [Accessed on March 14, 2015].

[30] Žager, K., Sačer Mamić, I., Sever, S. and Žager, L. (2009). Financial Statements Analysis (In Croatian). Zagreb: Masmedia. 


\section{APPENDICES}

Appendix 1: Data set for the indicators approach (in \%)

\begin{tabular}{|c|c|c|c|c|c|c|c|c|c|c|c|c|c|c|c|}
\hline \multicolumn{4}{|c|}{2008} & \multicolumn{3}{|c|}{2009} & \multicolumn{3}{|c|}{2010} & \multicolumn{3}{|c|}{2011} & \multicolumn{3}{|c|}{2012} \\
\hline EU-27 & IR & ROE & ROA & CIR & ROE & ROA & \begin{tabular}{ll|} 
CIR \\
\end{tabular} & ROE & ROA & $\begin{array}{ll}\text { CIR } \\
\end{array}$ & $\mathrm{ROE}$ & ROA & CIR & ROE & \\
\hline Austria & $-76,7$ & 1,7 & 0,1 & \begin{tabular}{|l|}
$-58,7$ \\
\end{tabular} & 2,8 & 0,2 & $-64,1$ & 6,41 & 0,46 & $-72,1$ & 1,47 & 0,1 & $-67,9$ & 4,14 & 0,31 \\
\hline $\mathrm{m}$ & -85 & 44,8 & $-1,5$ & $-76,7$ & $-2,4$ &, 1 & $\begin{array}{l}-64,6 \\
\end{array}$ & & & 5,7 & & 0,06 & $\begin{array}{l}-72 \\
\end{array}$ & 3,28 & \\
\hline (109 & $\overline{50}$ & 17,3 & & $-50,4$ & & 1.1 & $-48,8$ & 5,9 & & $\overline{50,1}$ & & 0,62 & & & $\overline{0,64}$ \\
\hline pru & & 14,7 & 0,9 & -51, & 10 & & -50, & 9,1 & & & & & & & \\
\hline ech Rep. & 1,4 & 14,6 & 1,1 & -42 & 17,1 & 1,4 & -46 & 15,2 & 28 & $-46,2$ & 13,7 & 1,16 & $-45,9$ & 14,1 & 1,36 \\
\hline rmany & -88 & $-9,8$ & $-0,3$ & $-69,8$ & $-1,8$ & & $-66,7$ & & & & & & & & \\
\hline enma & $-74,4$ & $-3,4$ & $-0,1$ & -55 & 3,8 & $-0,2$ & $-57,5$ & 2,39 & 11 & $-66,2$ & 0,6 & 0,03 & 9,9 & 2,04 & \\
\hline & & 16 & 13 & & & 34 & & & & & & & & & \\
\hline pain & & & & -42, & 8,8 & 0 & & & & & & & & & \\
\hline inland & & & 0, & -48 & 7,1 & 0,4 & -5 & & & & & 0, & 51,4 & 9,12 & 0,3 \\
\hline rance & & & 0 & $-67,3$ & 0 & & $\begin{array}{l}-64,7 \\
\end{array}$ & & 42 & $-66,3$ & 5,59 & 0,27 & $-70,4$ & 3,42 & 01 \\
\hline ireece & & 10,7 & 0,6 & -55 & 2,1 & 0,1 & $-58,7$ & $-4,7$ & $-0,31$ & $-61,7$ & $\mathrm{n} / \mathrm{a}$ & $\mathrm{n} / \mathrm{a}$ & $-72,2$ & -77 & $-2,9$ \\
\hline & & 15,1 & & $-41,7$ & & 1,7 & $-58,1$ & $\overline{0,}$ & & 8 & -7 & & -75 & -5 & \\
\hline & & 0,4 & & -38 & 6,1 & $-1,7$ & -412 & & & $-40,8$ & -11 & & $-92,7$ & & -0, \\
\hline & & & 0,3 & $-61,5$ & 4 & 0,3 & & 3,6 & & & -13 & & & $-0,9$ & -0 , \\
\hline huan & & & & -54 & $-70,1$ & & $-59,7$ & -3 & $-0,2$ & & 17 & & 56,5 & 9,66 & 0,9 \\
\hline & & & & & & 0,4 & & & & & & & & 7,46 & 0,49 \\
\hline atvia & & & & \begin{tabular}{|c|}
$-53,7$ \\
\end{tabular} & $-52,4$ & -4 & -7 & -21 & -16 & & 5, & 0 & & 6,01 & 0,5 \\
\hline & & & & & 17,6 & 1,8 & & & & & & & & & 1,1 \\
\hline & & & & & $-0,2$ & & & & & & & & $-65,3$ & 4,2 & 0,1 \\
\hline & & & & & & & & 9 & & & & & & 10,9 & 1, \\
\hline tugal & & & 0 & & 5,4 & & $-57,6$ & 6 , & 0,41 & & $-4,1$ & -0 & & -4 & $\overline{-0,}$ \\
\hline & & & & & 5, & & $-51,6$ & 2,9 & & & 1,25 & & & $-6,2$ & \\
\hline ede & & 12 & & -55 & 5,4 & 0, & -57 & 10,2 & & -58 & 10,7 & 0,4 & 55,6 & 9,62 & 0,44 \\
\hline & & & & & & & & & & & & & 34 & & \\
\hline & & & 0,8 & $-59,5$ & 5,6 & & $-54,5$ & 9,8 & 0,94 & -49, & 11,1 & 1,1 & $-60,3$ & 8,11 & 0,9 \\
\hline & -58.9 & $-9,7$ & $\frac{-0,4}{-0.4}$ & $-56,7$ & 0.4 & & $-60,3$ & 4.37 & 0,21 & 60,9 & 4.24 & 0,21 & $-70,1$ & 1.93 & \\
\hline
\end{tabular}

Appendix 2: Data set for DEA approach (amounts in EUR billions)

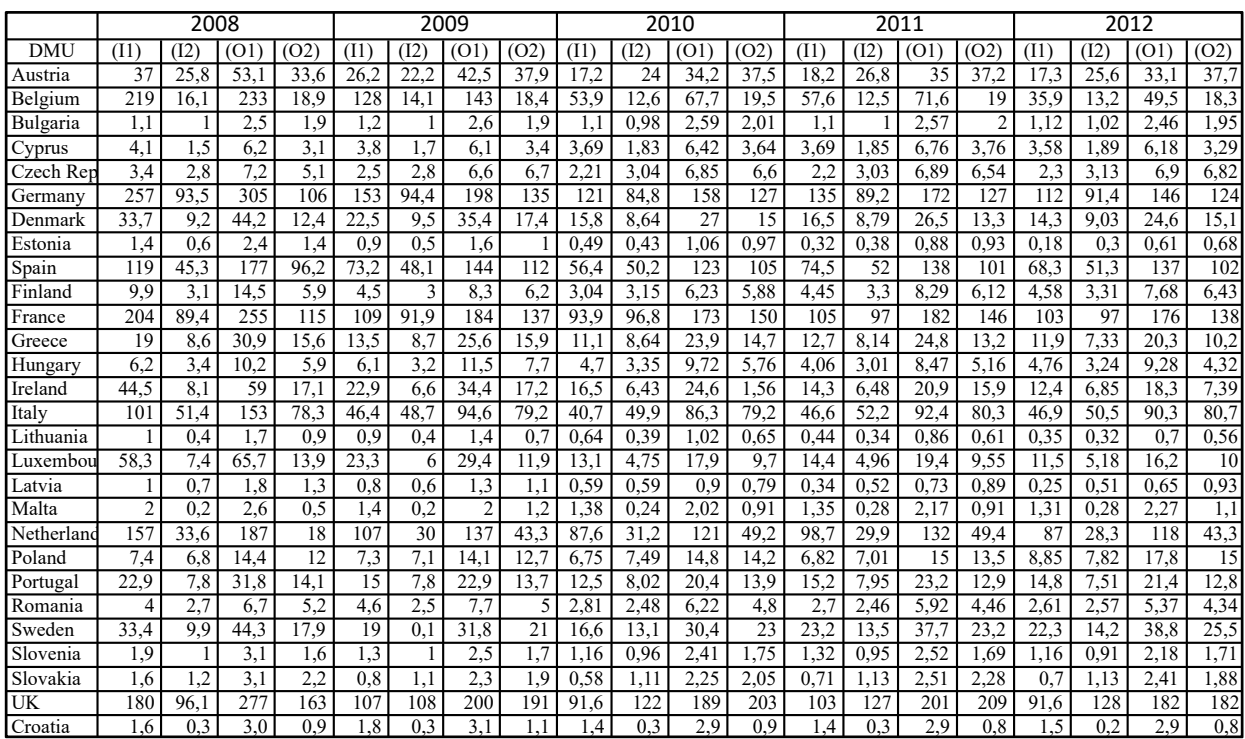


Appendix 3: CCR DEA model results - output oriented - CRS (excel output from DEA-

Solver-Pro)

\begin{tabular}{|c|c|c|c|c|c|c|c|c|c|c|c|c|c|c|}
\hline \multicolumn{3}{|c|}{2008} & \multicolumn{3}{|c|}{2009} & \multicolumn{3}{|c|}{2010} & \multicolumn{3}{|c|}{2011} & \multicolumn{3}{|c|}{2012} \\
\hline Ranl & DMU & Score & Rank & DMU & Score & Ranh & \begin{tabular}{|l|} 
DMU \\
\end{tabular} & Score & Ranh & \begin{tabular}{|l} 
DMU \\
\end{tabular} & Score & Ranh & \begin{tabular}{|l|} 
DMU \\
\end{tabular} & Score \\
\hline 1 & Croatia & 1 & 1 & Slovakia & 1 & 1 & Croatia & 1 & 1 & Croatia & 1 & 1 & Croatia & 1 \\
\hline 1 & Malta & 1 & 1 & \begin{tabular}{|l|l|} 
Sweden \\
\end{tabular} & 1 & 1 & \begin{tabular}{|l|l|} 
Slovakia \\
\end{tabular} & 1 & 1 & $\begin{array}{l}\text { Slovakia } \\
\end{array}$ & 1 & 1 & \begin{tabular}{|l|l|} 
Slovakia \\
\end{tabular} & 1 \\
\hline 1 & Belgium & 1 & 1 & \begin{tabular}{|l|} 
Czech Rep. \\
\end{tabular} & 1 & 1 & Malta & 1 & 1 & Malta & 1 & 1 & Malta & 1 \\
\hline 1 & Bulgaria & 1 & 4 & \begin{tabular}{|l|} 
Croatia \\
\end{tabular} & 0,956 & 1 & \begin{tabular}{|l} 
Czech Rep. \\
\end{tabular} & 1 & 1 & \begin{tabular}{|l|} 
Estonia \\
\end{tabular} & 1 & 1 & Estonia & 1 \\
\hline 1 & Estonia & 1 & 5 & Bulgaria & 0,903 & 5 & \begin{tabular}{|l|} 
Estonia \\
\end{tabular} & 0,979 & 5 & $\begin{array}{l}\text { Czech Rep. } \\
\end{array}$ & \begin{tabular}{|l|}
0,991 \\
\end{tabular} & 5 & \begin{tabular}{|l|} 
Latvia \\
\end{tabular} & 0,985 \\
\hline 6 & Lithuania & 0,957 & 6 & Hungary & 0,885 & 6 & \begin{tabular}{|l|} 
Spain \\
\end{tabular} & 0,908 & 6 & \begin{tabular}{|l} 
Ireland \\
\end{tabular} & 0,9 & 6 & \begin{tabular}{|l} 
Czech Rep. \\
\end{tabular} & 0,967 \\
\hline 7 & Czech Rep. & 0,953 & 7 & Spain & 0,878 & 7 & Bulgaria & 0,9 & 7 & Bulgaria & 0,861 & 7 & \begin{tabular}{|l} 
Bulgaria \\
\end{tabular} & 0,823 \\
\hline 8 & Romania & 0,947 & 8 & Greece & 0,849 & 8 & \begin{tabular}{|l|} 
Poland \\
\end{tabular} & 0,849 & 8 & \begin{tabular}{|l|l} 
Latvia \\
\end{tabular} & 0,827 & 8 & \begin{tabular}{|l} 
Spain \\
\end{tabular} & 0,811 \\
\hline 9 & Poland & 0,939 & 9 & \begin{tabular}{|l|} 
Estonia \\
\end{tabular} & 0,824 & 9 & Romania & 0,848 & 9 & \begin{tabular}{|l|} 
Poland \\
\end{tabular} & 0,807 & 9 & \begin{tabular}{|l|} 
Poland \\
\end{tabular} & 0,788 \\
\hline 10 & Slovakia & 0,926 & 10 & Slovenia & 0,821 & 10 & Finland & 0,83 & 10 & Romania & 0,796 & 10 & Hungary & 0,785 \\
\hline 11 & Latvia & 0,921 & 11 & Finland & 0,818 & 11 & Greece & 0,805 & 11 & $\begin{array}{l}\text { Cyprus } \\
\end{array}$ & 0,779 & 11 & Slovenia & 0,762 \\
\hline 12 & Spain & 0,885 & 12 & \begin{tabular}{|l|} 
Malta \\
\end{tabular} & 0,796 & 12 & Hungary & 0,795 & 12 & Hungary & 0,777 & 12 & \begin{tabular}{|l|} 
Finland \\
\end{tabular} & 0,751 \\
\hline 13 & Cyprus & 0,856 & 13 & Italy & 0,788 & 13 & Slovenia & 0,794 & 13 & Spain & 0,759 & 13 & Romania & 0,749 \\
\hline 14 & Greece & 0,824 & 14 & Ireland & 0,782 & 14 & \begin{tabular}{|l|} 
Cyprus \\
\end{tabular} & 0,787 & 14 & Greece & 0,756 & 14 & \begin{tabular}{|l|} 
Lithuania \\
\end{tabular} & 0,748 \\
\hline 15 & Hungary & 0,823 & 15 & Romania & 0,78 & 15 & UK & 0,762 & 15 & \begin{tabular}{|l|} 
Lithuania \\
\end{tabular} & 0,753 & 15 & \begin{tabular}{|l|} 
Cyprus \\
\end{tabular} & 0,747 \\
\hline 16 & Slovenia & 0,798 & 16 & $\begin{array}{l}\text { Cyprus } \\
\end{array}$ & 0,779 & 16 & Sweden & 0,753 & 16 & \begin{tabular}{|l|} 
Slovenia \\
\end{tabular} & 0,745 & 16 & Sweden & 0,728 \\
\hline 17 & UK & 0,794 & 17 & Denmark & 0,771 & 17 & Luxembour: & 0,732 & 17 & Finland & 0,743 & 17 & Denmark & 0,715 \\
\hline 18 & Finland & 0,773 & 18 & Poland & 0,768 & 18 & \begin{tabular}{|l|} 
Austria \\
\end{tabular} & 0,724 & 18 & \begin{tabular}{|l|} 
UK \\
\end{tabular} & 0,692 & 18 & Greece & 0,706 \\
\hline 19 & Luxembour & 0,767 & 19 & \begin{tabular}{|l} 
Lithuania \\
\end{tabular} & 0,756 & 19 & \begin{tabular}{|l|} 
Italy \\
\end{tabular} & 0,723 & 19 & Italy & 0,683 & 19 & \begin{tabular}{|l|} 
Italy \\
\end{tabular} & 0,684 \\
\hline 20 & Portugal & 0,747 & 20 & \begin{tabular}{|l|} 
UK \\
\end{tabular} & 0,732 & 20 & \begin{tabular}{|l|} 
Portugal \\
\end{tabular} & 0,719 & 20 & Luxembour: & 0,675 & 20 & Luxembour & 0,683 \\
\hline 21 & Italy & 0,742 & 21 & Portugal & 0,718 & 21 & Denmark & 0,716 & 21 & \begin{tabular}{|l|} 
Sweden \\
\end{tabular} & 0,674 & 21 & \begin{tabular}{|l|} 
Portugal \\
\end{tabular} & 0,654 \\
\hline 22 & Ireland & 0,73 & 22 & Latvia & 0,699 & 22 & France & 0,689 & 22 & \begin{tabular}{|l|} 
Austria \\
\end{tabular} & 0,654 & 22 & Austria & 0,641 \\
\hline 23 & Sweden & 0,715 & 23 & France & $\begin{array}{ll}0,699 \\
\end{array}$ & 23 & \begin{tabular}{|l} 
Lithuania \\
\end{tabular} & 0,688 & 23 & Denmark & 0,649 & 23 & \begin{tabular}{|l} 
Netherlands \\
\end{tabular} & 0,64 \\
\hline 24 & Denmark & 0,692 & 24 & Austria & 0,674 & 24 & \begin{tabular}{|l|} 
Ireland \\
\end{tabular} & 0,655 & 24 & France & 0,643 & 24 & \begin{tabular}{|l|} 
Belgium \\
\end{tabular} & 0,638 \\
\hline 25 & Austria & 0,668 & 25 & Luxembours & 0,666 & 25 & \begin{tabular}{|l|} 
Germany \\
\end{tabular} & 0,626 & 25 & Portugal & 0,638 & 25 & UK & 0,634 \\
\hline 26 & Netherlands & 0,642 & 26 & Netherlands & 0,665 & 26 & Netherlands & 0,614 & 26 & \begin{tabular}{|l|} 
Netherlands \\
\end{tabular} & 0,595 & 26 & France & 0,631 \\
\hline 27 & France & 0,627 & 27 & \begin{tabular}{|l|} 
Belgium \\
\end{tabular} & 0,632 & 27 & \begin{tabular}{|l|} 
Belgium \\
\end{tabular} & 0,594 & 27 & \begin{tabular}{|l|} 
Belgium \\
\end{tabular} & 0,575 & 27 & Ireland & 0,628 \\
\hline 28 & Germany & 0,609 & 28 & Denmark & 0,585 & 28 & Latvia & 0,593 & 28 & \begin{tabular}{|l} 
Germany \\
\end{tabular} & 0,55 & 28 & \begin{tabular}{|l} 
Germany \\
\end{tabular} & 0,537 \\
\hline
\end{tabular}

Source: author's calculation

Appendix 4: BCC DEA model results - output oriented - VRS (excel output from DEASolver-Pro)

\begin{tabular}{|c|c|c|c|c|c|c|c|c|c|c|c|c|c|c|}
\hline \multicolumn{3}{|c|}{2008} & \multicolumn{3}{|c|}{2009} & \multicolumn{3}{|c|}{2010} & \multicolumn{3}{|c|}{2011} & \multicolumn{3}{|c|}{2012} \\
\hline Rant & DMU & Score & Ranh & DMU & Score & Rank & DMU & Score & Rank & DMU & Score & Rank & DMU & Score \\
\hline 1 & Croatia & 1 & 1 & Croatia & \begin{tabular}{|l|}
1 \\
\end{tabular} & 1 & Croatia & \begin{tabular}{|l}
1 \\
\end{tabular} & 1 & Croatia & 1 & 1 & Croatia & 1 \\
\hline 1 & UK & 1 & 1 & UK & 1 & 1 & UK & 1 & 1 & UK & 1 & 1 & Austria & 1 \\
\hline 1 & Belgium & 1 & 1 & Belgium & 1 & 1 & Belgium & 1 & 1 & Belgium & 1 & 1 & UK & 1 \\
\hline 1 & Bulgaria & 1 & 1 & \begin{tabular}{|l|} 
Slovakia \\
\end{tabular} & 1 & 1 & Slovakia & 1 & 1 & Slovakia & 1 & 1 & Slovakia & 1 \\
\hline 1 & Romania & 1 & 1 & Sweden & 1 & 1 & Netherland & 1 & 1 & \begin{tabular}{|l} 
Netherlands \\
\end{tabular} & 1 & 1 & Netherlands & 1 \\
\hline 1 & Czech Rep. & 1 & 1 & \begin{tabular}{|l} 
Czech Rep. \\
\end{tabular} & 1 & 1 & Czech Rep & 1 & 1 & \begin{tabular}{|l} 
Czech Rep. \\
\end{tabular} & 1 & 1 & Czech Rep. & 1 \\
\hline 1 & Germany & 1 & 1 & \begin{tabular}{|l|} 
Germany \\
\end{tabular} & 1 & 1 & Malta & 1 & 1 & \begin{tabular}{|l|} 
Malta \\
\end{tabular} & 1 & 1 & Malta & 1 \\
\hline 1 & Poland & 1 & 1 & \begin{tabular}{|l|} 
Malta \\
\end{tabular} & 1 & 1 & Luxembou & 1 & 1 & Lithuania & 1 & 1 & Latvia & 1 \\
\hline 1 & Estonia & 1 & 1 & Estonia & 1 & 1 & Estonia & 1 & 1 & Estonia & 1 & 1 & Estonia & 1 \\
\hline 1 & Spain & 1 & 1 & \begin{tabular}{|l|} 
Spain \\
\end{tabular} & 1 & 1 & Spain & 1 & 1 & Spain & 1 & 1 & Spain & 1 \\
\hline 1 & Malta & 1 & 1 & \begin{tabular}{|l|} 
Latvia \\
\end{tabular} & 1 & 1 & Greece & 1 & 1 & Italy & 1 & 1 & France & 1 \\
\hline 1 & Latvia & 1 & 1 & Lithuania & 1 & 1 & France & 1 & 1 & France & 1 & 12 & Italy & 0,974 \\
\hline 1 & Greece & 1 & 1 & Italy & 1 & 13 & Lithuania & 1 & 1 & Greece & 1 & 13 & Luxembour & 0,97 \\
\hline 1 & Lithuania & 1 & 14 & France & 0,971 & 14 & Italy & 0,981 & 1 & Ireland & 1 & 14 & \begin{tabular}{|l} 
Belgium \\
\end{tabular} & 0,959 \\
\hline 1 & Ireland & 1 & 15 & Netherland: & 0,939 & 15 & Germany & 0,97 & 15 & Poland & 0,991 & 15 & Poland & 0,936 \\
\hline 16 & Luxembour & 0,988 & 16 & \begin{tabular}{|l|} 
Greece \\
\end{tabular} & 0,934 & 16 & Ireland & 0,968 & 16 & Germany & 0,975 & 16 & Sweden & 0,933 \\
\hline 17 & \begin{tabular}{|l|} 
Italy \\
\end{tabular} & 0,981 & 17 & Hungary & 0,912 & 17 & Denmark & 0,967 & 17 & \begin{tabular}{|l|} 
Austria \\
\end{tabular} & 0,957 & 17 & Hungary & 0,931 \\
\hline 18 & Finland & 0,96 & 18 & \begin{tabular}{|l|} 
Bulgaria \\
\end{tabular} & 0,907 & 18 & Austria & 0,949 & 18 & \begin{tabular}{|l|} 
Cyprus \\
\end{tabular} & 0,95 & 18 & Denmark & 0,909 \\
\hline 19 & Slovakia & 0,947 & 19 & \begin{tabular}{|l|} 
Poland \\
\end{tabular} & 0,88 & 19 & Hungary & 0,945 & 19 & Luxembour: & 0,941 & 19 & Greece & 0,906 \\
\hline 20 & Netherlands & 0,947 & 20 & Austria & 0,839 & 20 & Poland & 0,93 & 20 & \begin{tabular}{|l|} 
Hungary \\
\end{tabular} & 0,934 & 20 & Finland & 0,901 \\
\hline 21 & \begin{tabular}{|l} 
Cyprus \\
\end{tabular} & 0,93 & 21 & Denmark & $\begin{array}{ll}0,836 \\
\end{array}$ & 21 & Bulgaria & 0,911 & 21 & Sweden & 0,921 & 21 & Portugal & 0,886 \\
\hline 22 & Portugal & 0,926 & 22 & Finland & $\begin{array}{ll}0,836 \\
\end{array}$ & 22 & Cyprus & 0,901 & 22 & Denmark & 0,914 & 22 & Germany & 0,885 \\
\hline 23 & Hungary & 0,923 & 23 & Ireland & 0,829 & 23 & Romania & 0,892 & 23 & Latvia & 0,891 & 23 & Cyprus & 0,866 \\
\hline 24 & Denmark & 0,922 & 24 & Slovenia & 0,824 & 24 & Sweden & 0,871 & 24 & Portugal & 0,886 & 24 & Bulgaria & 0,841 \\
\hline 25 & Sweden & 0,918 & 25 & Romania & 0,783 & 25 & Finland & 0,856 & 25 & \begin{tabular}{|l|} 
Finland \\
\end{tabular} & 0,875 & 25 & Ireland & 0,826 \\
\hline 26 & France & 0,906 & 26 & Portugal & 0,78 & 26 & Portugal & 0,854 & 26 & Bulgaria & 0,871 & 26 & Romania & 0,803 \\
\hline 27 & Austria & 0,894 & 27 & \begin{tabular}{|l|} 
Cyprus \\
\end{tabular} & 0,78 & 27 & Slovenia & 0,808 & 27 & Romania & 0,866 & 27 & Slovenia & 0,782 \\
\hline 28 & Slovenia & 0,814 & 28 & Luxembour & 0,703 & 28 & Latvia & 0,618 & \begin{tabular}{l|l}
28 \\
\end{tabular} & Slovenia & 0,757 & 28 & Lithuania & 0,75 \\
\hline
\end{tabular}

Source: author's calculation 
Appendix 5: Output-orientated results of the window analysis DEA technique-CRS (excel output from DEA-Solver-Pro)

\begin{tabular}{|c|c|c|c|c|c|}
\hline \multicolumn{6}{|c|}{ Average by Term } \\
\hline DMU & 2008 & 2009 & 2010 & 2011 & 2012 \\
\hline Austria & 0,55 & 0,622 & 0,652 & 0,597 & 0,626 \\
\hline Belgium & $\mathbf{0 , 5 7 8}$ & $\mathbf{0 , 5 7 7}$ & $\overline{0,576}$ & $\mathbf{0 , 5 7 5}$ & $\overline{0,596}$ \\
\hline Bulgaria & 0,813 & $\mathbf{0 , 7 9 7}$ & $\mathbf{0 , 8 5 3}$ & $\mathbf{0 , 8 4}$ & $\mathbf{0 , 7 9 2}$ \\
\hline Cyprus & $\mathbf{0 , 6 7 2}$ & 0,69 & 0,729 & 0,763 & $\overline{0,703}$ \\
\hline Czech Rep. & $\mathbf{0 , 7 7 8}$ & $\mathbf{0 , 9 3 1}$ & 0,968 & 0,973 & 0,95 \\
\hline Germany & 0,513 & $\overline{0,524}$ & $\overline{0,524}$ & 0,513 & $\overline{0,499}$ \\
\hline Denmark & $\mathbf{0 , 5 9 1}$ & 0,674 & $\overline{0,694}$ & 0,649 & 0,678 \\
\hline Estonia & 0,751 & $\overline{\mathbf{0 , 7 3 2}}$ & $\overline{0,824}$ & $\mathbf{0 , 9 6 6}$ & 1 \\
\hline Spain & $\overline{0,664}$ & $\overline{0,801}$ & 0,806 & $\overline{0,731}$ & $\overline{0,769}$ \\
\hline Finland & $\mathbf{0 , 6 5 4}$ & $\overline{\mathbf{0 , 7 4}}$ & $\mathbf{0 , 7 3 2}$ & 0,718 & 0,671 \\
\hline France & $\overline{0,524}$ & 0,619 & $\overline{0,641}$ & $\overline{0,624}$ & 0,606 \\
\hline Greece & 0,686 & $\overline{0,744}$ & 0,79 & 0,754 & 0,665 \\
\hline Hungary & 0,672 & $\mathbf{0 , 8}$ & $\mathbf{0 , 7 7 8}$ & $\mathbf{0 , 7 7 6}$ & $\overline{0,741}$ \\
\hline Ireland & 0,627 & 0,701 & 0,638 & 0,663 & $\mathbf{0 , 5 9}$ \\
\hline Italy & 0,619 & 0,699 & $\mathbf{0 , 6 9 2}$ & 0,666 & 0,664 \\
\hline Lithuania & 0,746 & 0,659 & $\overline{0,64}$ & $\mathbf{0 , 7 3 6}$ & 0,721 \\
\hline Luxembourg & 0,57 & $\mathbf{0 , 5 8 4}$ & 0,614 & 0,603 & 0,616 \\
\hline Latvia & 0,705 & 0,643 & $\mathbf{0 , 5 4 1}$ & $\mathbf{0 , 7 3 6}$ & 0,985 \\
\hline Malta & $\overline{0,681}$ & $\mathbf{0 , 7 5 7}$ & $\mathbf{0 , 7 2 7}$ & $\overline{0,773}$ & $\overline{0,845}$ \\
\hline Netherlands & $\mathbf{0 , 5 5 2}$ & $\mathbf{0 , 5 7 2}$ & 0,599 & 0,594 & $\mathbf{0 , 5 9 7}$ \\
\hline Poland & 0,707 & $\mathbf{0 , 7}$ & 0,763 & 0,777 & 0,745 \\
\hline $\begin{array}{l}\text { Portugal } \\
\end{array}$ & 0,616 & 0,637 & 0,651 & 0,627 & 0,61 \\
\hline Romania & 0,675 & $\overline{0,699}$ & $\overline{\mathbf{0 , 8 0 4}}$ & $\overline{0,782}$ & $\overline{0,72}$ \\
\hline Sweden & 0,598 & 1 & 0,691 & 0,658 & 0,692 \\
\hline Slovenia & 0,662 & $\mathbf{0 , 7 2}$ & 0,765 & $\mathbf{0 , 7 3}$ & 0,718 \\
\hline Slovakia & 0,738 & 0,865 & 1 & 1 & 0,963 \\
\hline UK & 0,635 & 0,677 & 0,682 & 0,663 & 0,624 \\
\hline Croatia & 0,869 & $\mathbf{0 , 8 4 8}$ & 0,972 & 1 & 0,943 \\
\hline Average & 0,659 & 0,715 & 0,727 & 0,732 & 0,726 \\
\hline
\end{tabular}

\begin{tabular}{|l|r|}
\hline \multicolumn{2}{|c}{ Average through Window } \\
\hline \multicolumn{1}{|c|}{ DMU } & $\mathbf{2 0 0 8 - 1 2}$ \\
\hline Germany & $\mathbf{0 , 5 1 4 5 0 1}$ \\
\hline Belgium & $\mathbf{0 , 5 8 0 4 5 5}$ \\
\hline Netherlands & $\mathbf{0 , 5 8 2 7 6 8}$ \\
\hline Luxembourg & $\mathbf{0 , 5 9 7 4 9 3}$ \\
\hline France & $\mathbf{0 , 6 0 2 7 7 9}$ \\
\hline Austria & $\mathbf{0 , 6 0 9 1 3 9}$ \\
\hline Portugal & $\mathbf{0 , 6 2 8 0 5 2}$ \\
\hline Ireland & $\mathbf{0 , 6 4 3 6 6}$ \\
\hline UK & $\mathbf{0 , 6 5 6 2 3 3}$ \\
\hline Denmark & $\mathbf{0 , 6 5 7 0 6 3}$ \\
\hline Italy & $\mathbf{0 , 6 6 7 9 3 2}$ \\
\hline Lithuania & $\mathbf{0 , 7 0 0 3 3 5}$ \\
\hline Finland & $\mathbf{0 , 7 0 3 1 5 6}$ \\
\hline Cyprus & $\mathbf{0 , 7 1 1 4 2 4}$ \\
\hline Slovenia & $\mathbf{0 , 7 1 9 1 0 1}$ \\
\hline Latvia & $\mathbf{0 , 7 2 2 1 6 9}$ \\
\hline Sweden & $\mathbf{0 , 7 2 7 7 9 4}$ \\
\hline Greece & $\mathbf{0 , 7 2 7 8 9 7}$ \\
\hline Romania & $\mathbf{0 , 7 3 6 0 8 3}$ \\
\hline Poland & $\mathbf{0 , 7 3 8 1 0 5}$ \\
\hline Hungary & $\mathbf{0 , 7 5 3 2 7 5}$ \\
\hline Spain & $\mathbf{0 , 7 5 4 2 1 8}$ \\
\hline Malta & $\mathbf{0 , 7 5 6 3 8 7}$ \\
\hline Bulgaria & $\mathbf{0 , 8 1 8 9 5 2}$ \\
\hline Estonia & $\mathbf{0 , 8 5 4 6 0 3}$ \\
\hline Slovakia & $\mathbf{0 , 9 1 3 0 7}$ \\
\hline Czech Rep. & $\mathbf{0 , 9 2 0 0 9 2}$ \\
\hline Croatia & $\mathbf{0 , 9 2 6 3 4 3}$ \\
\hline & \\
\hline
\end{tabular}

Source: author's calculation 